\title{
Herminiimonas saxobsidens sp. nov., isolated from a lichen-colonized rock
}

\author{
Elke Lang, ${ }^{1}$ Jolantha Swiderski, ${ }^{1}$ Erko Stackebrandt, ${ }^{1}$ P. Schumann, ${ }^{1}$ \\ Cathrin Spröer ${ }^{1}$ and Nurettin Sahin ${ }^{2}$
}

Correspondence

Elke Lang

ela@dsmz.de

\author{
${ }^{1} \mathrm{DSMZ}$ - Deutsche Sammlung von Mikroorganismen und Zellkulturen GmbH, \\ Inhoffenstraße 7b, 30124 Braunschweig, Germany \\ ${ }^{2}$ Mugla University, Egitim Fakültesi, TR-48170 Kötekli, Mugla, Turkey
}

The genus Herminiimonas was established in the family Oxalobacteraceae, order Burkholderiales, class Betaproteobacteria, to accommodate an organism isolated from a borehole source of bottled drinking water (Herminiimonas fonticola; Fernandes et al., 2005). Two additional species in the genus, Herminiimonas aquatilis isolated from drinking water (Kämpfer et al., 2006) and Herminiimonas arsenicox$y$ dans isolated from arsenic-contaminated activated sludge (Muller et al., 2006), were described shortly thereafter. In contrast to the aqueous habitat of these three species, strain $\mathrm{NS} 11^{\mathrm{T}}$, determined herein to represent a novel species of the genus Herminiimonas, was isolated from the lichenrock interface of a limestone bedrock colonized by lichen at Mugla, Turkey, from enrichment cultures with potassium oxalate as the sole source of carbon and energy (Sahin et al., 2002). The lichen-rock interface contains a zone with high oxalate content. Oxalic acid produced by the lichen communities accelerates weathering of the rock by solubilizing the cement between the rock grains (Johnston \& Vestal, 1993).

The following DSMZ strains were used as reference: $H$. aquatilis DSM $18803^{\mathrm{T}}$, H. arsenicoxydans DSM $17148^{\mathrm{T}}$ and

The GenBank/EMBL/DDBJ accession number for the 16S rRNA gene sequence of strain $\mathrm{NS} 11^{\top}$ is $\mathrm{AM} 493906$.

A figure showing the diversity of normalized ribotype patterns and a dendrogram showing the fatty-acid relationships among the type strains of species of the genus Herminiimonas are available as supplementary material with the online version of this paper.
H. fonticola DSM $18555^{\mathrm{T}}$. Strain $\mathrm{NS}^{\mathrm{T}}$ was grown routinely on nutrient agar (per litre: $5 \mathrm{~g}$ peptone, $3 \mathrm{~g}$ beef extract, $15 \mathrm{~g}$ agar; Difco), and the type strains of the three recognized Herminiimonas species on R2A medium (Difco; Reasoner \& Geldreich, 1985) at $28{ }^{\circ} \mathrm{C}$.

From enrichment cultures with $4 \mathrm{~g}$ potassium oxalate $\mathrm{l}^{-1}$ as the sole source of carbon and energy in mineral medium (Aragno \& Schlegel, 1992), a Gram-negative, rod-shaped bacterium, designated strain $\mathrm{NS}_{1}{ }^{\mathrm{T}}$, was isolated (Sahin et al., 2002). Cells were motile, non-sporulating and strictly aerobic. Colonies of strain $\mathrm{NS}_{1} 1^{\mathrm{T}}$ were cream coloured and convex. Addition of oxalate $\left(2 \mathrm{~g} \mathrm{l}^{-1}\right)$ to nutrient agar did not enhance growth.

$16 \mathrm{~S}$ rRNA gene sequences were produced and aligned as described by Somvanshi et al. (2006). Phylogenetic dendrograms were constructed by using the neighbourjoining algorithm (De Soete, 1983). Analysis of the almostcomplete 16S rRNA gene sequence of strain $\mathrm{NS}_{1} 1^{\mathrm{T}}$ grouped it within the family Oxalobacteraceae. Highest sequence similarities were found with members of the genus Herminiimonas (Fig. 1), namely with $H$. arsenicoxydans $\mathrm{ULPAs}^{\mathrm{T}}(98.8 \%), H$. aquatilis CCUG $36956^{\mathrm{T}}$ $(98.0 \%)$ and $H$. fonticola S-94 ${ }^{\mathrm{T}}(98.0 \%)$.

Ribotyping of strains was performed with the automated RiboPrinter microbial characterization system (Qualicon; DuPont). Riboprint analyses, using restriction enzyme EcoRI, were performed according to the methods described by Allerberger \& Fritschel (1999). The fragment patterns of 


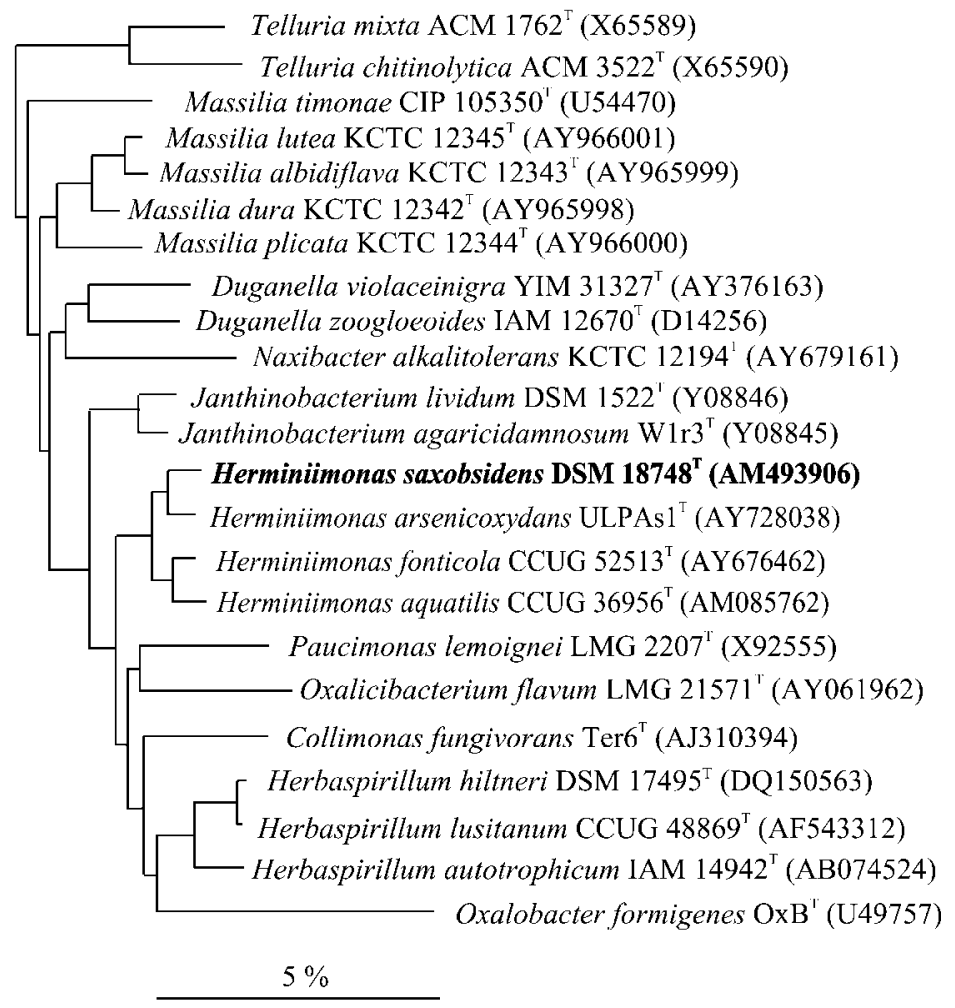

Fig. 1. Phylogenetic dendrogram (De Soete, 1983), based on 16S rRNA gene sequences, showing the nearest neighbours of strain $\mathrm{NS} 11^{\top}$ within the genus Herminiimonas, class Betaproteobacteria. Bar, $5 \%$ difference in nucleotide sequences, as determined by measuring the lengths of the horizontal lines connecting any two organism positions.

strain $\mathrm{NS}_{11}{ }^{\mathrm{T}}$ and of the type strains of the three recognized Herminiimonas species varied, resulting in a unique pattern for each of the strains (see Supplementary Fig. S1 in IJSEM Online). This dissimilarity between the ribopatterns for strain $\mathrm{NS}_{1} 1^{\mathrm{T}}$ and reference Herminiimonas type strains excludes the possibility that strain $\mathrm{NS} 11^{\mathrm{T}}$ is affiliated to any of the three recognized Herminiimonas species.

For DNA-DNA hybridization experiments, DNA was isolated using a French pressure cell (Thermo Spectronic) and was purified by chromatography on hydroxyapatite as described by Cashion et al. (1977). Hybridization was carried out in SSC buffer at $69{ }^{\circ} \mathrm{C}$ as described by De Ley et? al. (1970), with the modifications given by Huß et al. (1983), by using a model Cary 100 Bio Uv/vIS spectrophotometer equipped with a Peltier-thermostatted $6 \times 6$ multicell changer and a temperature controller with in situ temperature probe (Varian). The level of DNA-DNA relatedness between strain $\mathrm{NS}_{1} 1^{\mathrm{T}}$ and $H$. arsenicoxydans DSM $17148^{\mathrm{T}}$, sharing a $16 \mathrm{~S}$ rRNA gene sequence similarity of $98.8 \%$, was $22.4 \%$, which confirms that strain $\mathrm{NS}_{1} 1^{\mathrm{T}}$ does not belong to the genospecies $H$. arsenicoxydans. The level of DNA-DNA relatedness between $H$. aquatilis CCUG $36956^{\mathrm{T}}$ and $H$. fonticola S-94 ${ }^{\mathrm{T}}$, sharing a $16 \mathrm{~S}$ rRNA gene sequence similarity value of $99.3 \%$, was similarly low (25.7\%) (Kämpfer et al., 2006). These low hybridization values support a previous report of the lack of high levels of DNA-DNA reassociation even at 16S rRNA gene sequence similarities as high as around $99 \%$ (Stackebrandt \& Ebers, 2006).
For analysis of fatty acids, cells were grown on R2A agar for $48 \mathrm{~h}$ at $28{ }^{\circ} \mathrm{C}$. This growth medium, rather than the trypticase soy agar recommended for analysis according to the MIDI system, was used as strain $\mathrm{NS}_{11}{ }^{\mathrm{T}}$ and the Herminiimonas reference strains did not grow well on the latter medium. Fatty acid methyl esters were obtained by saponification, methylation and extraction as described by Kämpfer \& Kroppenstedt (1996) and separated by GC (model 5898A; Hewlett Packard). Peaks were automatically integrated and fatty-acid components and their proportions were determined by using the Microbial Identification standard software package MIDI (Sasser, 1990). Fatty acids of strain $\mathrm{NS}_{1} 1^{\mathrm{T}}$ were dominated by $\mathrm{C}_{16: 0}$ (36.4\%), $\mathrm{C}_{17: 0}$ cyclo $(22.3 \%)$ and $\mathrm{C}_{16: 1} \omega 7 c$ (18.7\%) (Table 1). The presence of $\mathrm{C}_{10: 0} 3-\mathrm{OH}$ as a significant component was also characteristic. The fatty acid patterns generated in the present study only partially agree with those provided in the species descriptions previously given for $H$. aquatilis, $H$. fonticola and $H$. arsenicoxydans. Although some components differed slightly only in quantity, a significant deviation was the absence of $\mathrm{C}_{17: 1} \omega 6 c$ in $H$. aquatilis DSM $18803^{\mathrm{T}}$, which is described to be present in $H$. aquatilis CCUG $36956^{\mathrm{T}}$ by Kämpfer et al. (2006). $\mathrm{C}_{17: 1} \omega 6 c$ is absent in four $H$. fonticola strains (Fernandes et al., 2005) and in H. arsenicoxydans ULPAs1 ${ }^{\mathrm{T}}$ (Muller et al., 2006). Possibly, the choice of the growth medium and age of cells used has influenced the fatty-acid composition. A dendrogram of Euclidian distances depicts the separate position of strain $\mathrm{NS}_{1} 1^{\mathrm{T}}$, confirming the result of 16S rRNA gene sequence analysis and riboprinting, i.e. 
Table 1. Whole-cell fatty acid composition of strain $\mathrm{NS} 11^{\top}$ and recognized Herminiimonas species

Strains: 1 , NS11 $1^{\mathrm{T}} ; 2, H$. arsenicoxydans DSM $17148^{\mathrm{T}} ; 3, H$. aquatilis DSM $18803^{\mathrm{T}} ; 4$, H. fonticola DSM $18555^{\mathrm{T}}$. Cultivation was on R2A medium for 2 days at $28{ }^{\circ} \mathrm{C}$. Data are percentages of total fatty acids. Data in parentheses were taken from Muller et al. (2006).

\begin{tabular}{|lcccc|}
\hline Fatty acid & $\mathbf{1}$ & $\mathbf{2}$ & $\mathbf{3}$ & $\mathbf{4}$ \\
\hline $\mathrm{C}_{10: 0}$ & 0.3 & $0.3(-)$ & $0.4(-)$ & $0.4(0.5)$ \\
$\mathrm{C}_{10: 0} 3-\mathrm{OH}$ & 7.3 & $6.0(8.0)$ & $5.6(5.2)$ & $6.3(6.0)$ \\
$\mathrm{C}_{14: 0}$ & - & $4.2(5.0)$ & $0.3(-)$ & $4.4(4.8)$ \\
$\mathrm{C}_{15: 1} \omega 6 c$ & - & $-(-)$ & $0.4(3.6)$ & $-(-)$ \\
$\mathrm{C}_{15: 0}$ & - & $-(-)$ & $1.3(2.8)$ & $-(-)$ \\
$\mathrm{C}_{16: 1} \omega 7 c$ & 18.7 & $32.6(52.7)$ & $44.4(47.7)$ & $45.5(45.6)$ \\
$\mathrm{C}_{16: 0}$ & 36.4 & $29.5(20.4)$ & $25.9(11.9)$ & $26.4(26.1)$ \\
$\mathrm{C}_{17: 0}$ cyclo & 22.3 & $16.1(3.3)$ & $8.4(-)$ & $8.3(7.9)$ \\
$\mathrm{C}_{17: 1} \omega 6 c$ & - & $-(-)$ & $-(16.0)$ & $-(-)$ \\
$\mathrm{C}_{18: 1} \omega 7 c$ & 8.1 & $4.2(6.6)$ & $10.3(9.1)$ & $7.8(7.3)$ \\
$\mathrm{C}_{18: 0}$ & 0.8 & $0.8(-)$ & $1.0(-)$ & $0.4(0.3)$ \\
$\mathrm{C}_{18: 1} 11-$ methyl $\omega 7 c$ & 0.6 & $3.7(-)$ & $-(-)$ & $-(-)$ \\
$\mathrm{C}_{19: 0}$ cyclo $\omega 8 c$ & 6.2 & $1.7(-)$ & $0.5(-)$ & $0.5(0.4)$ \\
\hline
\end{tabular}

the distinct position of strain NS11 ${ }^{\mathrm{T}}$ among the type strains of recognized Herminiimonas species (see Supplementary Fig. S2 in IJSEM Online).

Physiological and biochemical tests were performed at $28{ }^{\circ} \mathrm{C}$. Conventional biochemical tests were performed according to standard methods (Smibert \& Krieg, 1994). API 20NE, API ZYM and API $50 \mathrm{CH}$ strips (bioMérieux) were used according to the manufacturer's instructions, except that nitrate reduction and indole production from tryptophan were read after 2 days, whereas other reactions of the API 20NE and API $50 \mathrm{CH}$ strips were observed after 7 days. Utilization and assimilation of carbohydrates was determined on API $50 \mathrm{CH}$ strips with modified AUX medium in which growth factors and amino acids were replaced by $0.1 \mathrm{~g}$ yeast extract $\mathrm{l}^{-1}$. Biolog GN plates (AES) were incubated for $48 \mathrm{~h}$ before being read. Cavities showing a photometric value above 20 or 100 were scored as weak or positive, respectively.

Physiologically, strain $\mathrm{NS}^{\mathrm{T}}{ }^{\mathrm{T}}$ was characterized by poor reactivity. Several organic acids but no carbohydrates or sugar alcohols were metabolized in Biolog GN plates (Table 2). None of the carbohydrates offered in the API $20 \mathrm{NE}$ or API $50 \mathrm{CH}$ strips was utilized. The enzyme reactions found for strain $\mathrm{NS}_{1}{ }^{\mathrm{T}}$ with API ZYM strips as given in the species description below are in good agreement with those reported for strains of $H$. fonticola (Muller et al., 2006). These characteristics of strain NS11 ${ }^{\mathrm{T}}$ are generally in accordance with those described for the three recognized Herminiimonas species and differentiate these species from members of the closely related genus Janthinobacterium, which utilize carbohydrates (Lincoln et al., 1999). Nevertheless, strain NS11 ${ }^{\mathrm{T}}$ was more versatile than the type strains of the three recognized
Herminiimonas species in the Biolog GN plates. Under the given conditions, strain $\mathrm{NS}_{1} 1^{\mathrm{T}}$ was able to assimilate, among others, acetate, DL-malate, propionate and succinate. Utilization of these organic acids by strain $\mathrm{NS}_{1} 1^{\mathrm{T}}$ as the sole source of carbon and energy was confirmed in mineral medium (Table 2).

Interestingly, some substrates which did not result in tetrazolium staining in Biolog GN plates promoted growth when offered as the sole source of carbon. These included acetic acid, propionic acid and succinic acid for $H$. arsenicoxydans DSM $17148^{\mathrm{T}}$. One of the possible reasons for this was the difference in incubation times, which were, respectively, $48 \mathrm{~h}$ and 10 days in our study. No such discrepancy between the results obtained with the Biolog GN or growth tests was noted for strain $\mathrm{NS}_{1}{ }^{\mathrm{T}}$. Comparison of our test results for $H$. fonticola DSM $18555^{\mathrm{T}}$ and H. aquatilis DSM $18803^{\mathrm{T}}$ and the results given by Fernandes et al. (2005) and Kämpfer et al. (2006) for the respective species reveals that results are reproducible from

Table 2. Differential characteristics between strain $\mathrm{NS} 11^{\top}$ and the type strains of recognized Herminiimonas species

Strains: $1, \mathrm{NS}_{1} 1^{\mathrm{T}} ; 2, H$. arsenicoxydans DSM $17148^{\mathrm{T}} ; 3, H$. fonticola DSM $18555^{\mathrm{T}} ; 4$, H. aquatilis DSM $18803^{\mathrm{T}}$. Biolog GN and API $20 \mathrm{NE}$ reactions were read after 2 days at $28{ }^{\circ} \mathrm{C}$. All strains are positive for oxidase and (Biolog plates) DL-lactic acid and pyruvic acid methyl ester, weak for L-arabinose but negative for the other panel substrates or reactions not detailed. Biolog GN cavities showing a photometric value above 20 or 100 were scored weak (w) or positive $(+)$, respectively. Reactions with different results in a second independent experiment are separated by a slash. All strains are positive for growth in mineral medium with acetate, oxalate and succinate as the substrate within 10 days of incubation.

\begin{tabular}{|c|c|c|c|c|}
\hline Reaction & 1 & 2 & 3 & 4 \\
\hline \multicolumn{5}{|l|}{ Biolog GN } \\
\hline Acetic acid & + & $\mathrm{w} /-$ & - & $\mathrm{w} /-$ \\
\hline Bromosuccinic acid & + & - & - & - \\
\hline Succinamic acid & + & - & - & - \\
\hline Formic acid & + & $+/ \mathrm{w}$ & $\mathrm{w} /-$ & $+/ \mathrm{w}$ \\
\hline D-Alanine & + & W & - & $\mathrm{w} /-$ \\
\hline Propionic acid & $+/ \mathrm{w}$ & - & - & - \\
\hline$\alpha$-Hydroxybutyric acid & + & $\mathrm{w} /-$ & - & - \\
\hline Succinic acid & $+/ \mathrm{w}$ & - & - & - \\
\hline L-Arabinose & $\mathrm{w} /-$ & $\mathrm{w}$ & $\mathrm{w}$ & $\mathrm{w} /-$ \\
\hline \multicolumn{5}{|l|}{ API 20NE } \\
\hline $\begin{array}{l}\text { Nitrate reduction, nitrite } \\
\text { production }\end{array}$ & + & + & - & + \\
\hline Malate utilization & + & - & + & - \\
\hline Citrate utilization & - & - & + & - \\
\hline \multicolumn{5}{|l|}{ Growth in mineral medium } \\
\hline Propionate & + & + & + & - \\
\hline DL-Malate & + & - & + & - \\
\hline Citrate & - & - & + & - \\
\hline
\end{tabular}


laboratory to laboratory if the same method (microplates or mineral medium in tubes) is applied.

The specific growth rate $(\mu)$ of strain $\mathrm{NS}_{1} 1^{\mathrm{T}}$ with oxalate as the sole source of carbon and energy was $0.112 \mathrm{~h}^{-1}$ $\left(t_{\mathrm{d}}=6.2 \mathrm{~h}\right)$ at $4 \mathrm{~g}$ potassium oxalate $1^{-1}$ and $30^{\circ} \mathrm{C}$. No growth was observed in the presence of $20 \mathrm{~g}$ potassium oxalate $\mathrm{l}^{-1}$. Resistance to antibiotics as well as resistance to heavy metal ions were determined as described by Sahin $e t$ al. (2002). The results are given in the species description below. Both strain NS11 $1^{\mathrm{T}}$ and $H$. arsenicoxydans were tolerant to heavy metals, although different metal elements were tested for the two taxa (Sahin et al., 2002; Muller et al., 2006).

The inability to utilize carbohydrates, the utilization of short-chain organic acids and the fatty-acid profile were in agreement with the placement of strain $\mathrm{NS}^{\mathrm{T}}{ }^{\mathrm{T}}$ within the genus Herminiimonas as suggested by the phylogenetic analysis. On the other hand, some traits distinguished strain $\mathrm{NS} 11^{\mathrm{T}}$ from the type strains of the three recognized species in the genus Herminiimonas (assimilation reactions with acetic acid, propionic acid, $\alpha$-hydroxybutyric acid, succinic acid, bromosuccinic acid, succinamic acid; utilization of malate but not of citrate; and lack of $\mathrm{C}_{14: 0}$

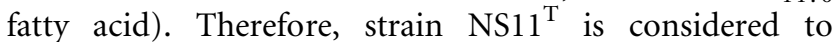
represent a novel species of the genus Herminiimonas, for which the name Herminiimonas saxobsidens sp. nov. is proposed.

\section{Description of Herminiimonas saxobsidens sp. nov.}

Herminiimonas saxobsidens (sax.ob'si.dens. L. n. saxum rock; L. v. obsideo to occupy; N.L. part. adj. saxobsidens rock-occupying).

Cells are Gram-negative, small ovoid rods $0.8 \times 0.4 \mu \mathrm{m}$, motile by means of polar flagella. Cells occur singly or in pairs. No spores are found. Non-pigmented. Forms round, translucent, cream-coloured, convex colonies with flat margins, reaching $1.5 \mathrm{~mm}$ in diameter on nutrient agar after 3 days incubation. Growth occurs at $4-37^{\circ} \mathrm{C}$. Optimum growth occurs at $\mathrm{pH} 7.0-7.5$. Weak growth occurs in media containing $2 \% \mathrm{NaCl}$. No acid is produced from glucose. Oxidase- and catalase-positive. Nitrate is reduced to nitrite but not further to dinitrogen. Alkaline phosphatase, $\mathrm{C}_{4}$-esterase, $\mathrm{C}_{8}$-esterase lipase, leucine arylamidase, trypsin and phosphohydrolase are produced. Negative for indole production, arginine dihydrolase, urease, aesculin, casein and gelatin hydrolysis, and $\beta$ galactosidase. Has a very limited substrate spectrum. Does not utilize carbohydrates or polyols. Utilizes acetate, propionate, oxalate, succinate and malate. Does not utilize adipate, citrate, gluconate, caprate, malonate or ethanol. Predominant fatty acids are $\mathrm{C}_{16: 0}, \mathrm{C}_{17: 0}$ cyclo and $\mathrm{C}_{16: 1} \omega 7 c, \mathrm{C}_{18: 1} \omega 7 c$ and $\mathrm{C}_{10: 0} 3-\mathrm{OH}$ are present in smaller amounts. Does not contain $\mathrm{C}_{14: 0}$. Resistant to ampicillin, bacitracin and streptomycin $(10 \mu \mathrm{g}$ per disc each), but susceptible to erythromycin $(15 \mu \mathrm{g})$, chloramphenicol $(30 \mu \mathrm{g})$ and gentamicin $(10 \mu \mathrm{g})$. Sensitive to $\mathrm{HgCl}_{2}$
(2.5 $\mu \mathrm{g}$ per disc), but resistant to $\mathrm{ZnSO}_{4} \cdot 7 \mathrm{H}_{2} \mathrm{O}$, $\mathrm{NiCl}_{2} \cdot 6 \mathrm{H}_{2} \mathrm{O}, \mathrm{CoCl}_{2} \cdot 6 \mathrm{H}_{2} \mathrm{O}, \mathrm{CuSO}_{4} \cdot 5 \mathrm{H}_{2} \mathrm{O}$, lead acetate and $\mathrm{K}_{2} \mathrm{CrO}_{7}(2.5 \mu \mathrm{g}$ per disc each).

The type strain, $\mathrm{NS}_{11}{ }^{\mathrm{T}}\left(=\mathrm{DSM} 18748^{\mathrm{T}}=\mathrm{CCM} 7436^{\mathrm{T}}\right)$, was isolated from limestone covered by lichen after enrichment with oxalate in mineral medium.

\section{Acknowledgements}

We wish to thank R. Kroppenstedt for providing fatty acid analyses, and M. Kopitz, P. Aumann, S. Welnitz, I. Kramer, B. Sträubler and J. Gregor for excellent technical assistance.

\section{References}

Allerberger, F. \& Fritschel, S. J. (1999). Use of automated ribotyping of Austrian Listeria monocytogenes isolates to support epidemiological typing. J Microbiol Methods 35, 237-244.

Aragno, M. \& Schlegel, H. G. (1992). The mesophilic hydrogenoxidizing (Knallgas) bacteria. In The Prokaryotes, 2nd edn, pp. 344384. Edited by A. Balows, H. G. Trüper, M. Dworkin, W. Harder \& K. H. Schleifer. Berlin: Springer.

Cashion, P., Holder-Franklin, M. A., McCully, J. \& Franklin, M. (1977). A rapid method for base ratio determination of bacterial DNA. Anal Biochem 81, 461-466.

De Ley, J., Cattoir, H. \& Reynaerts, A. (1970). The quantitative measurement of DNA hybridization from renaturation rates. Eur $J$ Biochem 12, 133-142.

De Soete, G. (1983). A least squares algorithm for fitting additive trees to proximity data. Psychometrika 48, 621-626.

Fernandes, C., Rainey, F. A., Nobre, M. F., Pinhal, I., Folhas, F. \& da Costa, M. S. (2005). Herminiimonas fonticola gen. nov., sp. nov., a Betaproteobacterium isolated from a source of bottled mineral water. Syst Appl Microbiol 28, 596-603.

Huß, V. A. R., Festl, H. \& Schleifer, K.-H. (1983). Studies on the spectrophotometric determination of DNA hybridization from renaturation rates. Syst Appl Microbiol 4, 184-192.

Johnston, C. G. \& Vestal, J. R. (1993). Biogeochemistry of oxalate in the antarctic cryptoendolithic lichen-dominated community. Microb Ecol 25, 305-319.

Kämpfer, P. \& Kroppenstedt, R. M. (1996). Numerical analysis of fatty acid patterns of coryneform bacteria and related taxa. Can J Microbiol 42, 989-1005.

Kämpfer, P., Busse, H.-J. \& Falsen, E. (2006). Herminiimonas aquatilis sp. nov., a new species from drinking water. Syst Appl Microbiol 29, 287-291.

Lincoln, S. P., Fermor, T. R. \& Tindall, B. J. (1999). Janthinobacterium agaricidamnosum sp. nov., a soft rot pathogen of Agaricus bisporus. Int J Syst Bacteriol 49, 1577-1589.

Muller, D., Simeonova, D. D., Riegel, P., Mangenot, S., Koechler, S., Lièvremont, D., Bertin, P. N. \& Lett, M.-C. (2006). Herminiimonas arsenicoxydans sp. nov., a metalloresistant bacterium. Int J Syst Evol Microbiol 56, 1765-1769.

Reasoner, D. J. \& Geldreich, E. E. (1985). A new medium for the enumeration and subculture of bacteria from potable water. Appl Environ Microbiol 49, 1-7.

Sahin, N., Gökler, I. \& Tamer, A. Ü. (2002). Isolation, characterization and numerical taxonomy of novel oxalate-oxidizing bacteria. J Microbiol 40, 109-118. 
Sasser, M. (1990). Identification of bacteria by gas chromatography of cellular fatty acids. USFCC Newsl 20, 16.

Smibert, R. M. \& Krieg, N. R. (1994). Phenotypic characterization. In Methods for General and Molecular Bacteriology, pp. 607-654. Edited by P. Gerhardt, R. G. E. Murray, W. A. Wood \& N. R. Krieg. Washington, DC: American Society for Microbiology.
Somvanshi, V. S., Lang, E., Sträubler, B., Spröer, C., Schumann, P., Ganguly, S., Saxena, A. K. \& Stackebrandt, E. (2006). Providencia vermicola sp. nov., isolated from infective juveniles of the entomopathogenic nematode Steinernema thermophilum. Int J Syst Evol Microbiol 56, 629-633.

Stackebrandt, E. \& Ebers, J. (2006). Taxonomic parameters revisited: tarnished gold standard. Microbiol Today 33, 152-155. 